\title{
External Quality Assessment of Table Eggs Produced Under Cage and Deep Litter Housing Systems of Genesis Poultry Farm, Bishoftu, Ethiopia
} Yitagesu Belachew ${ }^{1}$, Birhanu Abera ${ }^{2}$, Tesfaye Dufera ${ }^{3}$, Eyob Eticha ${ }^{2}$ and Diriba Lemma ${ }^{2}$

${ }^{1}$ Sude District Livestock and Fishery Resource Office, Arsi Zone, Ethiopia

${ }^{2}$ Asella Regional Veterinary Laboratory, PO Box 212, Asella, Ethiopia

${ }^{3}$ North Shoa Zone Livestock and Fishery Resource Office, Fitche, Ethiopia

\begin{abstract}
The present study was designed to assess the External Quality Assessment of Table Eggs Produced in cage and deep litter poultry housing systems. The study was under taken during a period of six months (November to May), on Genesis commercial poultry farm, which is found in Bishoftu town. A total of 1200 eggs from both housing systems were studied for physical characteristics. The results showed that there were highly significant $(p<0.05)$ difference regarding egg cleanness between age groups, but eggs shape and size defects were not significantly associated with age in both housing systems. Percentage results of 1200 egg sampled from cage and deep litter housing system revealed that $16.6 \%$ and $20.2 \%$ table eggs were lost due to deterioration from cage and deep litter housing systems respectively. In conclusion, both housing system under study revealed very small (negligible) abnormal size and shape. Therefore; awareness about the management and carefully handling practice of eggs should be organized to create well-informed poultry farms and consumers to maintain egg quality then offer safe and good quality eggs for consumption.
\end{abstract}

Keywords: Deep litter; Cage; External egg quality; Genesis; Poultry

\section{Introduction}

The poultry sector in Ethiopia can be characterized into three major production systems based on some selected parameters such as breed, flock size, housing, feeding, health, technology and bio-security. These are large scale commercial poultry production system, smallscale commercial poultry production system and village or backyard poultry production system [1].

Poultry breeding is generally acceptable to people all over the world and provides an excellent source of protein especially for poor rural communities, because it requires little capital, labour and land. Poultry birds are good converters of feed into usable protein in meat and egg [2]. In commercial egg laying farming enterprise, the success depends on the total number and size of egg produced. Commercial layer strains produce eggs for food and egg processing industries [3].

Egg quality refers to group of all traits that influence the use of eggs as foodstuff [4]. Among many quality characteristics, external factors including cleanliness, freshness, and egg weight and shell quality are important in consumer's acceptability of shelled eggs [5]. Unlike external quality, the internal quality of eggs starts to decline as soon as they are laid by hens. Thus, although factors associated with the management and feeding of hens can play a role in external egg quality, internal egg quality, egg handling and storage practices also have a significant impact on the quality of eggs reaching consumers.

Worldwide, production of eggs of good shell quality (external quality) is critical to the economic viability of the egg industry [6]. The booming business activities in the study area are encouraging the community to give breakfast and dinner outdoor where egg dishes are highly consumed. To satisfy the increasing demand for egg dishes, restaurant owners and street food vendors need sufficient supply of quality eggs from the market. The physical appearance of an egg makes the first impression upon the consumer. If the product does not meet perceived expectations, consumer confidence diminishes [7]. Therefore, external characteristic of eggs are prerequisite for safety, soundness and wholesomeness of the eggs [8]. In light of these, the study was conducted to evaluate external quality of chicken table eggs produced under cage and deep litter housing systems of Genesis commercial poultry farm, Bishoftu, Ethiopia.

\section{Materials and Methods}

The study was done in Genesis farms. Genesis farm is an integrated big farm which found in Bishoftu town, East Shoa zone, Oromia region, from November -may, on Bovans brown poultry breed produced for table egg production.

\section{Description of the study area}

The study was done in Genesis farms. Genesis farm is an integrated big farm which found in Bishoftu town. Bishoftu town is located 47 $\mathrm{km}$ east of Addis Ababa. Bishoftu town is found in the east shoa zone of Oromia regional state, central Ethiopia at located at $9^{\circ} \mathrm{N}$ latitude and $4^{\circ} \mathrm{E}$ longitude at an attitude of 1850 meter above sea level. It has an annual rainfall of $866 \mathrm{~mm}$ of which $84 \%$ is the long rainy season (June to September). The dry season extends from October to February. The mean annual maximum and minimum temperatures are $26^{\circ} \mathrm{C}$ and $14^{\circ} \mathrm{C}$, respectively, with mean relative humidity of $61.3 \%$ [9]. In addition to its proximity to the capital city, Bishoftu is one of the most scenic locations in the country with crater lakes, which is beautifying

*Corresponding author: Birhanu Abera, Asella Regional Veterinary Laboratory, PO Box 212, Asella, Ethiopia, Tel: +0913333944; E-mail: birhanuabera27@ yahoo.com

Received December 08, 2016; Accepted January 04, 2017; Published January 06, 2017

Citation: Belachew Y, Abera B, Dufera T, Eticha E, Lemma D (2017) External Quality Assessment of Table Eggs Produced Under Cage and Deep Litter Housing Systems of Genesis Poultry Farm, Bishoftu, Ethiopia. J Vet Sci Technol 8: 410. doi: 10.4172/2157-7579.1000410

Copyright: @ 2017 Belachew Y, et al. This is an open-access article distributed under the terms of the Creative Commons Attribution License, which permits unrestricted use, distribution, and reproduction in any medium, provided the original author and source are credited. 
the town. Two types of poultry production system are found on this area; the back yard and the commercial poultry production system [10].

\section{Study design}

The study was based on farm inspection, and egg quality examination in cage and deep litter housing systems.

\section{Farm inspection}

During farm visits observational assessments were making on employees working conditions, housing systems, egg collection practices, and farm cleanness. The housing conditions were examined in detail in respect to ventilation, type of floor, bedding materials, space, nesting arrangements, water and feed trough space, feed and water trough cleanness.

\section{Egg examination}

Every two weeks, from November to May, a total of 1200 eggs were randomly sampled from a large batch eggs and evaluated for external quality characteristics such as cleanness, soundness, size and shape. Eggs were thoroughly checked for evidence of breakage or cracks. Egg shell cleanness and soundness were assessed according to US standard for quality of shell eggs [11]. Abnormality of size and shape were determined based on Rajkumar et al. procedure [12]

\section{Statistical analysis}

Descriptive statistics such as frequency and percentage were calculated and all the surveyed data were analyzed using SPSS version 20. The level of significance was also expressed using P-value less than 0.05

\section{Results}

\section{Farm inspection}

Cage production system: The cage system poultry house is semiopen type with concrete floor area of $300 \mathrm{~m}^{2}$. The roofing material used is corrugated iron sheet. The open sides of the house are covered internally with plastic mesh and externally with plastic. The external covering were removed during day times to facilitate ventilation and closed at night. Mechanical ventilation was also used at times of high ambient temperature. The lighting system used was 100 watt bulbs. The houses were getting natural and/or artificial lights 20 hours per day. Poultry dropping were removed on regular daily basis. The feeding and watering activities fully automated.

They were three rows of cages, which were labeled $R_{1}, R_{2}$ and $R_{3}$. The length of one row is about 25 meters. Each row had two sides and on each side there were 116 cages horizontally and 3 cages vertically. Thus there were 696 cages in one row. The total number of cages was 2088 with each cage housing 5 layers. The holding capacity of the house was 10,440 layers.

The bio-security measures employed to protect the birds from health hazards were strict control of movements of outsiders and nonessential personnel in to poultry house boats and overalls for the farm employee and use of footbath (disinfectants) at the gates of the poultry houses. The employees working on fulltime bases were 5 in number (3 males and 2 females).

Eggs were collected on trays three times per day at 4:00, 7:00 and 10:00 local time. Egg trays were arranged on a rolling table. The collected eggs were placed on the trays. The collected eggs on the trays were then stocked in one corner of the building until delivery, which normally takes place on the same day. At the time of collection, damaged eggs were segregated and kept on separate trays.

Deep litter production system: The biosecurity measures were comparable to the cage housing system. There were around 300 nests arranged for egg laying. Although there was large number of nests quite non negligible number of hens lay on floor (litter).

In this litter system, there were two female workers. They collect eggs four to five times daily. However, there was no fixed time for egg collection. Within the same room the eggs were stocked until delivery to the market at farm center. At the time of collection damaged eggs were placed separately. Feeding and watering were done manually in such away that $400 \mathrm{~kg}$ of feed was distributed daily for 3000 layers.

Egg examination: During the 6 months observation period, a total of 1200 eggs, both from cage and litter housing systems were examined.

Cage system: The external quality assessment results of table eggs under cage system of housing are shown in Table 1 . All categories of external defects taken together, nearly $17 \%$ of the sampled eggs were of poor quality.

The frequency of defects on shape and size of table eggs have been assessed in the eggs produced under cage system. The result shows that the frequency of occurrence abnormal size /shape (0.4\%) was negligible and they are all clean (Table 2). The external quality assessment results of eggs in different age groups of layer chicken (Table 3). The effect of layers age on the external quality of the eggs has been assessed and age appeared to have significant effect $(\mathrm{p}=0.002)$ on egg cleanness (Table 4 ). The result showed that there were highly significant $(\mathrm{p}<0.05)$ difference regarding egg cleanness between age groups, but eggs shape and size defects were not significantly associated with age.

Deep litter system: The external quality assessment results of table eggs produced by flocks managed under deep litter system of housing presented in Table 5 . The proportion of poor quality eggs (all defects taken together) was found to be more than $20 \%$. The proportion of table eggs with size /shape defects in deep litter housing showed a $1.6 \%$

\begin{tabular}{|c|c|c|}
\hline External quality parameters & Number of eggs & Percent \\
\hline Clean & 1001 & 83.4 \\
\hline Fairly clean & 101 & 8.4 \\
\hline Dirty & 53 & 4.4 \\
\hline Broken & 45 & 3.8 \\
\hline Total & 1200 & 100.0 \\
\hline
\end{tabular}

Table 1: External quality assessment results of table eggs produced under cage system of housing.

\begin{tabular}{|c|c|c|}
\hline Shape/size & Number of Eggs & Percent \\
\hline Normal shape/size & 1195 & 99.6 \\
\hline Abnorml shape/size & 5 & 0.4 \\
\hline Total & 1200 & 100.0 \\
\hline
\end{tabular}

Table 2: Table eggs shape/size assessment results under cage system.

\begin{tabular}{|c|c|c|c|c|c|}
\hline \multirow{2}{*}{$\begin{array}{c}\text { Age category of } \\
\text { Layers }\end{array}$} & \multicolumn{5}{|c|}{ Egg Cleanness } \\
\cline { 2 - 6 } & Clean & Fairy clean & Dirty & Broken & Total \\
\hline$<80$ wks & 360 & 12 & 10 & 15 & 397 \\
\hline 80 to 90 wks & 391 & 56 & 31 & 21 & 499 \\
\hline$>90$ wks & 245 & 33 & 12 & 9 & 299 \\
\hline Total & 996 & 101 & 53 & 45 & 1195 \\
\hline
\end{tabular}

Table 3: External egg quality in different age groups of chicken managed under cage system of housing. 


\begin{tabular}{|c|c|c|c|c|c|c|}
\hline $\begin{array}{l}\text { External quality } \\
\text { parameters }\end{array}$ & $\begin{array}{c}\text { Age } \\
\text { category }\end{array}$ & $\begin{array}{l}\text { Sum of } \\
\text { squares }\end{array}$ & Df & $\begin{array}{l}\text { Mean } \\
\text { Squares }\end{array}$ & $\mathbf{F}$ & $P$ value \\
\hline \multirow{3}{*}{ Egg Cleanness } & $<80$ wks & \multirow{3}{*}{6.395} & \multirow{3}{*}{2} & \multirow{3}{*}{3.197} & \multirow{3}{*}{6.232} & \multirow{3}{*}{$0.002^{\star}$} \\
\hline & $\begin{array}{l}80 \text { to } 90 \\
\text { wks }\end{array}$ & & & & & \\
\hline & $>90$ wks & & & & & \\
\hline \multirow{3}{*}{ Size of egg } & $<80$ wks & \multirow{3}{*}{0.029} & \multirow{3}{*}{2} & \multirow{3}{*}{0.015} & \multirow{3}{*}{0.700} & \multirow{3}{*}{0.497} \\
\hline & $\begin{array}{c}80 \text { to } 90 \\
\text { wks }\end{array}$ & & & & & \\
\hline & $>90$ wks & & & & & \\
\hline \multirow{3}{*}{ Shape of egg } & $<80$ wks & \multirow{3}{*}{0.456} & \multirow{3}{*}{2} & \multirow{3}{*}{0.225} & \multirow{3}{*}{1.882} & \multirow{3}{*}{0.153} \\
\hline & $\begin{array}{l}80 \text { to } 90 \\
\text { wks }\end{array}$ & & & & & \\
\hline & $>90$ wks & & & & & \\
\hline
\end{tabular}

${ }^{*} \mathrm{P}<0.05$ : Statistically significant

Table 4: Effect of layers age on external quality of table eggs (cage system).

\begin{tabular}{|c|c|c|}
\hline $\begin{array}{c}\text { External quality } \\
\text { parameters }\end{array}$ & Number of Eggs & Percent \\
\hline Clean & 957 & 79.8 \\
\hline Fairly clean & 128 & 10.7 \\
\hline Dirty & 77 & 6.4 \\
\hline Broken & 38 & 3.2 \\
\hline Total & 1200 & 1200 \\
\hline
\end{tabular}

Table 5: External quality assessment results of table eggs produced in deep litter housing.

\begin{tabular}{|c|c|c|}
\hline Shape/size & Number of Eggs & Percent \\
\hline Normal size /shape & 1181 & 98.4 \\
\hline Abnormal size /shape & 19 & 1.6 \\
\hline Total & 1200 & 100.0 \\
\hline
\end{tabular}

Table 6: Table eggs shape/size assessment results under deep litter system.

\begin{tabular}{|c|c|c|c|c|c|}
\hline \multirow{2}{*}{$\begin{array}{c}\text { Age category of } \\
\text { layers }\end{array}$} & \multicolumn{5}{|c|}{ Egg Cleanness } \\
\cline { 2 - 6 } & Clean & Fairly clean & Dirty & Broken & Total \\
\hline$<80$ wks & 298 & 58 & 32 & 12 & 400 \\
\hline 80 to 90 wks & 420 & 45 & 23 & 12 & 500 \\
\hline$>90$ wks & 239 & 25 & 22 & 14 & 300 \\
\hline Total & 957 & 128 & 77 & 38 & 1200 \\
\hline
\end{tabular}

Table 7: External egg quality in different age groups of layer flocks (deep litter system).

abnormal size/shape (Table 6). The external assessment results of eggs in different age groups of layer chicken produced in deep litter system are illustrated in Table 7. The effect of age of layers chicken on external quality of egg under deep litter system of production is illustrated in Table 8. Age of the layers has a significant effect $(\mathrm{p}=0.009)$ on cleanness of the egg.

\section{Discussion}

As a single trait can hardly describe the external quality of an egg, four traits (shell cleanness, shell soundness and abnormal size and shape) were considered for determination of external quality. Different customer surveys revealed that freshness, un cracked shell, test, absence of inclusions and deep yolk color are the top five characteristics perceived as being indicative of quality [11].

The results of this survey revealed that out of 1200 table eggs sampled from cage system $83.4 \%$ (clean), $8.4 \%$ (fairly clean), $4.4 \%$ (dirty) and $3.8 \%$ (broken). The cause of egg shell dirtiness could probably be because of contamination with poultry droppings and egg soiling which can be due to decreasing cage slope and increasing stocking density. The investigations made before by Al-shami et al. [13] strengthen this idea. According to his investigation, the least dirty eggs were produced on the floor with the steepest slope $\left(9^{\circ}\right)$.

Table eggs obtained from layer of age between 80 and 90 weeks were highly broken when compared to other ages this can be caused by mechanical breakage during egg collection, reduction of the amount of calcium in the layer diet or due to older ages of the hens. Chowdurry and Smith explained that egg shell quality was improved with increasing dietery levels of calcium retention and calcium balance [14]. Additionally, in previous report Bekele et al. stated that as commercial layer's age, not only does egg production fall, but also egg shell quality deteriorates [15]. Moreover, it is assumed that as bird age their ability to produce egg shell decreases and so at the end of lay are thinner and hence weaker than those produced early in lay. More detailed information has been collected for trends egg laying flocks over the laying period Belyavin and Boorman [16].

Although our understanding of the reasons for the changes in calcium retention is incomplete, there is some evidence that they are connected with alterations in vitamin $\mathrm{D}_{3}$ metabolism; particularly the production of the metabolite has a number of effects. It stimulates calcium restoration from bone and helps prevent calcium being excreted in the urine. It also induces the cells lining the intestine to synthesize calcium binding proteins and increases calcium absorption from the gut. The in vitro production of $1,25(\mathrm{HH})_{2} \mathrm{D}_{3}$ by kidney tissue taken from laying birds during cell shell calcification was less in old compared with young bird [17]; inclusion of $1,25(\mathrm{HH})_{2} \mathrm{D}_{3}$ in the diet increases shell thickness in hens which have been in lays for 9 months [18]. This finding implies that the decline in shell quality with increasing flock age is related to a decreasing ability to absorb calcium from the intestine and to mobilize skeletal calcium. In addition to lack of calcium, it is well established that elevated environmental temperature is associated with decrease in shell quality, which leads to egg breakage [11].

In these study results of egg cleanness, abnormal size and abnormal shape of table eggs produced in the cage system reveal that age has significant effect on egg cleanness but it has no effect on abnormal size and shape of table eggs. There was a highly significant $(p<0.05)$ difference of egg cleanness within and between age groups but there was no significant $(\mathrm{p}<0.05)$ difference of abnormal shape.

In deep litter production system, the results of this survey revealed that out of 1200 eggs sampled from the deep litter system, $79.8 \%$ (clean), $10.7 \%$ (fairly clean), $6.4 \%$ (dirty) and 3.2\% (broken). The explanation for table eggshell dirtiness in deep litter system is mostly the same with that

\begin{tabular}{|c|c|c|c|c|c|c|}
\hline $\begin{array}{l}\text { External quality } \\
\text { parameters }\end{array}$ & Age category & $\begin{array}{l}\text { Sum of } \\
\text { squares }\end{array}$ & Df & $\begin{array}{c}\text { Mean } \\
\text { Squares }\end{array}$ & $\mathbf{F}$ & $P$ value \\
\hline \multirow{3}{*}{ Egg Cleanness } & $<80$ wks & \multirow{3}{*}{5.058} & \multirow{3}{*}{2} & \multirow{3}{*}{2.529} & \multirow{3}{*}{4.529} & \multirow{3}{*}{$0.009^{*}$} \\
\hline & 80 to 90 wks & & & & & \\
\hline & $>90$ wks & & & & & \\
\hline \multirow{3}{*}{ Size of egg } & $<80$ wks & \multirow{3}{*}{0.012} & \multirow{3}{*}{2} & \multirow{3}{*}{0.006} & \multirow{3}{*}{0.012} & \multirow{3}{*}{0.982} \\
\hline & 80 to 90 wks & & & & & \\
\hline & $>90$ wks & & & & & \\
\hline \multirow{3}{*}{ Shape of egg } & $<80$ wks & \multirow{3}{*}{0.072} & \multirow{3}{*}{2} & \multirow{3}{*}{0.036} & \multirow{3}{*}{0.600} & \multirow{3}{*}{0.549} \\
\hline & 80 to 90 wks & & & & & \\
\hline & $>90$ wks & & & & & \\
\hline
\end{tabular}

Table 8: Results of age effect on external quality of table eggs (deep litter system). 
Citation: Belachew Y, Abera B, Dufera T, Eticha E, Lemma D (2017) External Quality Assessment of Table Eggs Produced Under Cage and Deep Litter Housing Systems of Genesis Poultry Farm, Bishoftu, Ethiopia. J Vet Sci Technol 8: 410. doi: 10.4172/2157-7579.1000410

of the cage system. Additionally, in this housing system eggs can be laid by layers on floor outside their nest, which leads to eggs shell dirtiness. Furthermore the higher incidence of dirty eggs in the deep litter system as compared to cage system was reflected during external egg quality assessment. This can be explained by management difference between the two housing systems.

\section{Conclusion and Recommendations}

In developing country like Ethiopia commercial poultry production in cage and deep litter housing system is of great importance as supplier of egg and meat as a source of income. However, the quality of table eggs produced in both housing system is not as good as it is expected. Several factors are involved in quality deterioration of table eggs.

In this study it was observed that eggs produced in both housing system showed higher external egg quality deterioration, $16.6 \%$ and $20.2 \%$ in cage and deep litter housing system, respectively. Factors like improper handling, poultry house dirtiness, lack of calcium and high environmental temperature may be the cause of this egg quality deterioration. Based on the above conclusion, the following points are recommended:

The poultry houses should be kept clean and table eggs should be collected frequently

There should be adequate amount of calcium in the layers diet

Table egg layers should be replaced before aging

Awareness about the management and carefully handling practice of eggs should be organized and consumers to offer safe and good quality eggs for consumption.

Further study should be conducted to assess both external and internal quality of table eggs in the study area.

\section{Competing Interest}

The authors declare that they have no competing interest.

\section{Acknowledgements}

Authors would like to thank Genesis farms for their cooperation and support of this work.

\section{References}

1. Bush J (2006) The Threat of Avian Flu Predicted Impacts on Rural Livelihoods in Southern Nation, Nationalities and Peoples Region (SNNPR), Ethiopia. The Food Economy Group, May 2006.
2. Abanikanda OTF, Olutogun O, Leigh AO, Ajayi LA (2007) Statistical modelling of egg weight and egg dimensions in commercial layers. Int J Poultry Sci 6 : 59-63.

3. Olawumi SO, Adeoti Al (2009) Comparative economic analysis of black and brown commercial layer strains in Nigeria. Int J Poultry Sci 8: 1011-1103.

4. Schwaegele F (2003) Egg quality assurance system under aspect of the EU requirements and demand of the consumer. In: IX European Symposium on the quality of Eggs and Egg Products, September, Kusadasi, Turkey, Proceedings, pp: $435-443$

5. Sonaiya EB, Swan SEJ (2004) Small-scale poultry production, technical guide manual. FAO Animal Production and Health 1. FAO (Food and Agriculture Organization of the United Nations), Rome, Italy.

6. Ahmadi F, Rahimi $F$ (2011) Factors affecting quality and quantity of egg production in laying hens: A Review. World Appl Sci 12: 372-384.

7. Watkins S (2004) Clean Eggs-our most important merchandizing tool. National Egg Quality School Proceedings. Atlanta, GA 17: 54-60.

8. Kemps B, Bamelis F, De Ketelaere B, Mertens K, Tona K, et al. (2006) Visible transmission spectroscopy for assessment of egg freshness. J Sci Food Agr 86: $1399-1406$.

9. NMSA (2004) National Meteorological Service Agency, Ethiopia.

10. Zeleke A, Bizuneh T, Tesema T (2005) Historical milestones of Debre Zeit Agricultural Research Center, DARC in half a century (1995-2005) Bulletin of Golden Jubilee.

11. Matt D, Veromann E, Luik A (2009) Effect of housing systems on biochemical composition of chicken eggs. Agron Res 7: 662-667.

12. Rajkumar U, Sharma RP, Rajaravindra KS, Niranjan M, Chatterjee RN (2009) Effect of genotype and age on egg quality traits in naked neck chicken under tropical climate from India. Int J Poult Sci 8: 1151-1155.

13. Al-shami MA, Salih ME, Abbas TE (2011) Effects of dietary inclusion of alfalfa (Medicago sativa L.) leaf meal and Xylan enzyme on laying hens' performance and egg quality. Res Opin Anim Vet Sci 2: 14-18.

14. Chowdhury SR, Smith TK (2002) Dietary interaction of 1-4 diaminobutan (putrescine) and calcium on egg shell quality and performance in laying hens. Poultry Sci 81: 84-91.

15. Bekele F, Ånnøy T, Gjøen HM, Kathle J, Abebe G (2010) Production performance of dual purpose crosses of two indigenous with two exotic chicken breeds in sub-tropical environment. Int J Poult Sci 9: 702-710.

16. Belyavin CG, Boorman KN (1982) Crack type and severity as indications of shell quality. Poultry Science 61: 591-594.

17. Abe E, Hori FH, Masumura T, Sugatara M, Kubota M, et al (1982) Disorders of cholecalcefrol metabolism in old egg laying hens. J nutr 112: 436-446.

18. Morris KML, Jenkins S, Simonite JP (1977) The effect on egg shell thickness of inclusion of the carcinogenic plant Solanium nalacoxylan in the diet of laying hens. Veterinary Record 101: 502-504. 